DOI 10.18551/rjoas.2021-09.16

\title{
ANALYSIS OF CORRELATION AND AGRO-MORPHOLOGICAL TRAITS IN SINGLE CROSS HYBRIDS OF MAIZE
}

\author{
Sharma Hari Prasad*, Upadhyaya Jharana \\ Directorate of Agricultural Research, Nepal Agricultural Research Council, Khajura Banke, \\ Lumbini Province, Nepal \\ Shrestha Jiban \\ Nepal Agricultural Research Council, National Plant Breeding and Genetics Research \\ Centre, Khumaltar, Lalitpur, Nepal \\ *E-mail: harisharma.ag@gmail.com \\ ORCID: 0000-0003-0981-3772
}

\begin{abstract}
The objective of the present study was to estimate the correlation coefficients and assess agro-morphological variability of single cross hybrids of maize. This study was conducted at research field of National Maize Research Program, Rampur, Chitwan, Nepal during the winter season from October 6, 2015 to March 5, 2016. Fourteen single cross maize hybrids were evaluated to study correlation and agro-morphological traits. Single cross hybrid namely RML-98 / RL-105 (6229 kg ha $\left.{ }^{-1}\right)$ significantly produced the highest yield, followed by RM1-4 / NML-2 (6073 kg ha-1), RML-95 / RL-105 (5904 kg ha-1) and RML-5/RL-105 (5528 kg $\left.\mathrm{ha}^{-1}\right)$. Cob length was strongly correlated with cob diameter (0.885), number of kernels per row (0.812), number of kernel rows per cob (0.951), test weight (0.870) and grain yield (0.916). Similarly, cob diameter was strongly correlated with number of kernels per row (0.870), number of kernel rows per cob (0.934), test weight (0.922) and grain yield (0.946). The number of kernels per row was strongly correlated with number of kernel rows per cob (0.915), test weight $(0.781)$ and grain yield $(0.847)$. The number of kernel rows per cob was strongly correlated with test weight (0.902) and grain yield (0.942). Similarly, test weight was strongly correlated with grain yield $(0.968)$. The grain yield of the evaluated hybrids was significantly positively correlated with yield attributing traits. There was considerable variability among the hybrids evaluated for growth, grain yield, and traits indicating the presence of variation. Therefore, the results of this study suggest that farmers should grow maize hybrids RML-98 / RL-105, RM1-4 /NML-2, RML-95 / RL-105 and RML-5/RL-105 to achieve higher maize production.
\end{abstract}

\section{KEY WORDS}

Correlation, genetic variations, single cross maize hybrids.

Maize (Zea mays $L, 2 n=2 \times=20$ ), a member of the Gramineae family, is the second most important grain after rice and contributes to Nepal's agricultural economy in several ways. The area and productivity of maize were 9.6 million hectares and $2.96 \mathrm{mt} \mathrm{ha}{ }^{-1}$, respectively (MoAD, 2020). Similarly, the seed replacement rate of Nepalese maize is low (11.3\%) (Pokhrel, 2013). It has been reported that the demand for corn has increased by $5 \%$ in the last decade (Sapkota \& Pokhrel, 2010). This contributes to about a quarter of total grain production, $6.54 \%$ in AGDP and $3.15 \%$ in GDP (MoAD, 2013). It currently accounts for about $80 \%$ and $10 \%$ of maize production in Terai and Mid hills (Adhikari, 2014). Hybrid maize accounted for about 7\% to 10\% of Nepal's area in 2010 (Gurung et al. 2011), and hybrid maize acreage is increasing every year. Nepal annually imports about $20 \%$ of maize seeds (Adhikari, 2014) and almost 100\% of hybrid seeds from India (Gurung et al., 2011). However, around $40 \%$ to $45 \%$ of the corn kernels used in the animal feed industries is still imported from India each year (CDD, 2013). 
Genetic diversity plays an important role in plant breeding. In the description and classification of germplasm, morphological characterization is the first step (Smith \& Smith, 1989). Characterization of morphological variability is an important tool to identify germplasm with desirable traits such as early maturity, disease resistance, or improved ear traits. The characterization and grouping of the germplasm based on agro-morphological traits help the breeders to avoid duplication in the sample population (Shrestha, 2016). Qualitative and quantitative information on maize morphological characteristics may help maintain its genetic variability and protect them from genetic erosion (Lucchin et al., 2003). Khodambashi et al., (2012) stated that in breeding programs, understanding of the mode of inheritance of the yield components, the correlations among them and the association between each component and yield is necessary for an intelligent choice of breeding procedures for evolving high-yielding varieties. Correlation is the degree to which two or more variables are related and change together (Gomez \& Gomez, 1984). Hallauer and Miranda (1988) reported that correlation measures the degree of relevance between two or more traits and is measured by the correlation coefficient. It can be genotypic or phenotypic (non-genetic) in nature. The objective of the present study is to estimate the correlation coefficients and the agro-morphological variability in single cross hybrid of maize.

\section{MATERIALS AND METHODS OF RESEARCH}

Plant materials. Fourteen maize hybrids were evaluated in this study. All these hybrids were received from National Maize Research Program, Rampur, Chitwan, Nepal.

Table 1 - List of maize hybrids used in the experiment

\begin{tabular}{ll}
\hline Maize hybrids & Parentage line \\
\hline RML-4/RML-17 & CA00326/ CML-287 \\
RML-95/RML-96 & PUTU-17/ AG-27 \\
RML-32/RML-17 & CA00320/ CML-287 \\
RML-86/RML-96 & PUTU-20/ AG-27 \\
RML-5/RL-105 & CA00314/UPAHAR-B-20-2-4-1-1 \\
RML-95/RL-105 & PUTU-17/UPAHAR-B-20-2-4-1-1 \\
RML-115/RML-96 & PUTU-17/AG-27 \\
RML-153/RL-105 & POOL-21-12-1-2-1-1-1/UPAHAR-B-20-2-4-1-1 \\
RML-85/RL-105 & PUTU-14/UPAHAR-B-20-2-4-1-1 \\
RML-98/RL-105 & L-3/UPAHAR-B-20-2-4-1-1 \\
RML-4/NML-2 (RH-2) & CA00326/CML-430 \\
CP-666 & - \\
Bioseed-9681 & - \\
Rajkumar & - \\
\hline
\end{tabular}

Experimental Sites. The field experiment was conducted from the first week of October 6, 2015 to March 5, 2016 at the National Maize Research Program (NMRP) in Rampur, Chitwan, Nepal. The experimental site is located at $27^{\circ} 40^{\prime} \mathrm{N}, 84^{\circ} 21^{\prime} \mathrm{E}$ and $228 \mathrm{~m}$ above sea level. The soil of experimental site consisted of sandy loam (65.7\%), acidic soil (pH 5.43), high organic matter (3.95\%), medium available total nitrogen $(0.15 \%)$, high available phosphorus (33.76 ppm) and medium available potassium (145 ppm) (Khadka et al., 2016). The highest temperature recorded during the experiment was $27.32{ }^{\circ} \mathrm{C}$, and the lowest was $14.33^{\circ} \mathrm{C}$. The minimum temperature ranged from $8.76^{\circ} \mathrm{C}$ to $24.08^{\circ} \mathrm{C}$. The maximum amount of precipitation $(42.5 \mathrm{~mm})$ in October 2015 , the minimum precipitation $(4.66 \mathrm{~mm})$ in January. The total rainfall during crop growing season was $95.66 \mathrm{~mm}$.

Experimental design and cultural practices. Fourteen maize hybrids were evaluated in a randomized complete block design (RCBD) with three replications. The plot size was 2 rows of $3 \mathrm{~m}$ length and spacing was of $60 \mathrm{~cm} \times 25 \mathrm{~cm}$. The individual net plot was $3.6 \mathrm{~m}^{2}$ $(3 \mathrm{~m} \times 1.2 \mathrm{~m})$. Farm yard manure @ $10 \mathrm{t} \mathrm{ha}^{-1}$ and 180: 60: $40 \mathrm{~kg} \mathrm{~N}: \mathrm{P}: \mathrm{K} \mathrm{ha}^{-1}$ in the form of Urea, Di-ammonium phosphate, and Murate of Potash were used. Half dose of nitrogen and full dose of phosphorus and potassium was applied at the time of sowing. The remaining nitrogen was halved and applied on 30 DAS and 45 DAS. Atrazine $2.0 \mathrm{~g}+$ Pendimethalin 4.5 $\mathrm{ml} \mathrm{L}^{-1}$ water were used to control weeds. 
Data observation. Data on plant height, cob height, days to $50 \%$ silking, days to $50 \%$ tasseling, anthesis silking interval, test weight (1000 kernels weight), cob length, cob diameter, number of kernel rows per cob, number of kernels per row were recorded. Grain yield $\left(\mathrm{kg} \mathrm{ha}^{-1}\right)$ at $15 \%$ moisture content was calculated using fresh ear weight with the help of the below formula:

$$
\text { Grain yield }\left(\frac{\mathrm{kg}}{\mathrm{ha}}\right)=\frac{\mathrm{F} \cdot \mathrm{W} \cdot\left(\frac{\mathrm{kg}}{\mathrm{plot}}\right) \times(100-\mathrm{HMP}) \times \mathrm{S} \times 10000}{(100-\mathrm{DMP}) \times \mathrm{NPA}}
$$

Where: F.W. = Fresh weight of ear in $\mathrm{kg}$ per plot at harvest; HMP = Grain moisture percentage at harvest; DMP $=$ Desired moisture percentage, i.e. $15 \%$; NPA $=$ Net harvest plot area, $\mathrm{m}^{2} ; \mathrm{S}=$ Shelling coefficient, i.e. 0.8 .

This formula was also adopted by Carangal et al. (1971) and Shrestha et al. (2015) to adjust the grain yield $\left(\mathrm{kg} \mathrm{ha}^{-1}\right)$ at $15 \%$ moisture content. This adjusted grain yield $\left(\mathrm{kg} \mathrm{ha}^{-1}\right)$ was again converted to grain yield $\left(\mathrm{t} \mathrm{ha}^{-1}\right)$.

Data Analysis. The Pearson correlation coefficient of growth, yield and its attributing traits was worked out according to the procedure outlined. The correlation coefficient was calculated using SPSS 20.

$$
r=\frac{\sum_{i}\left(x_{i}-\bar{x}\right)\left(y_{i}-\bar{y}\right)}{\sqrt{\sum_{i}\left(x_{i}-\bar{x}\right)^{2}} \sqrt{\sum_{i}\left(y_{i}-\bar{y}\right)^{2}}}
$$

Where: $\mathrm{r}=$ Pearson correlation coefficient; $\mathrm{xi}=\mathrm{x}$ variable; $\mathrm{y} \mathrm{i}=\mathrm{y}$ variable; $\bar{x}=$ Mean of $\mathrm{x}$ variable; $\bar{y}=$ Mean of y variable.

All collected data were entered in computer software MS Excel version 16. A Tukey test was performed at a $5 \%$ level of significance. GenStat, version 18 was used to analyze data. Data was analyzed using one-way ANOVA. The means were separated by the least significant difference (LSD) with $\mathrm{P}<0.05$.

\section{RESULTS AND DISCUSSION}

Table 2 shows that the single cross hybrids RML-98/RL-105 and RML-95/RL-105 had the highest plant height $(196.7 \mathrm{~cm})$ while hybrid RML-32/RML-17 had the lowest plant height $(162.7 \mathrm{~cm})$. The maximum value of cob height was recorded in RML-85/RL-105 $(119.33 \mathrm{~cm})$ while the minimum value of it was recorded in RML-4/RML-17 $(90.67 \mathrm{~cm})$. Similarly, the highest value of days to $50 \%$ silking was given by RML-95/RML-96 (70.33 days) and the lowest value of it in Bio-9681 (49 days). There was variation in days to $50 \%$ tasseling, the highest days to $50 \%$ tasseling was found in RML-95/RML-96 (65.67 days) and the lowest value of it was found in Bio-9681 (45 days). The highest anthesis-silking interval (ASI) was recorded in RML-4/RML-17 and RML-4/NML-2 (5 day), while Bio-9681 and CP 666 had the lowest ASI (4.0 days). There was huge variation in number of kernels per row, the highest number of kernels per row was found in RML-5/RL-105 and RML-98/RL-105 (36.33) whereas the lowest number of kernels per row (27) was found in Rajkumar. RML-85/RL-105 and RML-95/RL-105 had the highest number of kernel rows per cob (17.33) while Rajkumar had the lowest value of it (14). The highest cob length was recorded in RML-153/RL-105 (16.69 $\mathrm{cm})$ while RML-115/RML-96 had the lowest cob length $(12.81 \mathrm{~cm})$. Similarly, the maximum cob diameter was found in RML-115/RML-96 $(7.68 \mathrm{~cm})$ whereas Rajkumar had the lowest cob diameter $(4.8 \mathrm{~cm})$. There was large variation was recorded in grain yield and test weight; RML-98/RL-105 produced the maximum grain yield and the highest test weight $(6229 \mathrm{~kg} \mathrm{ha}$ ${ }^{1}$ and $395.7 \mathrm{~g}$ ) while Rajkumar produced the lowest grain yield $\left(4087 \mathrm{~kg} \mathrm{ha}^{-1}\right)$ and RML$32 / R M L-17$ had the lowest test weight $(4358.3 \mathrm{~g})$. Among fourteen hybrids; nine hybrids viz. RML-98/RL-105, RML-4/NML-2, RML-95/RL-105, RML-4/RML-17, RML-5/RL-105, RML- 
153/RL-105, RML-85/RL105, RML-115/RML-96 and RML-86/RML-96 had grain yield $>5000$ $\mathrm{kg} \mathrm{ha}^{-1}$. Five hybrids namely Bioseed-9681, CP-666, RML-95/RML-96, RML-32/RML-17, Rajkumar, had produced yield between $>4087 \mathrm{~kg}$ to $<5000 \mathrm{~kg} \mathrm{ha}^{-1}$.

Table 2 - Growth, yield and its attributing traits of single cross maize hybrids

\begin{tabular}{|c|c|c|c|c|c|c|c|c|c|c|c|}
\hline Maize hybrids & $\mathrm{PH}$ & $\mathrm{CH}$ & DTT & DTS & ASI & $\mathrm{CL}$ & CD & $\mathrm{NKR} / \mathrm{C}$ & NK/R & TW & GY \\
\hline RML-4/RML-17 & 172 & 90.67 & 56 & 61 & 5 & 15.93 & 7.667 & 16 & 33.67 & 375.7 & 5552 \\
\hline CP 666 & 165 & 95.33 & 46 & 50 & 4 & 14.23 & 5.2 & 14.67 & 26.33 & 335.3 & 4579 \\
\hline Bio-9681 & 171.7 & 98.33 & 45 & 49 & 4 & 14.33 & 5 & 14.67 & 27.33 & 344 & 4832 \\
\hline RML-95/RML-96 & 183.3 & 114.33 & 65.67 & 70.33 & 4.667 & 13.93 & 7.233 & 16 & 28.67 & 354 & 4528 \\
\hline RML-32/RML-17 & 162.7 & 94.33 & 65 & 69.67 & 4.667 & 15.8 & 7.133 & 15.33 & 33.67 & 347 & 4358 \\
\hline RML-86/RML-96 & 182.3 & 108.67 & 63.67 & 68 & 4.333 & 15.33 & 7.333 & 16.67 & 32 & 371 & 5154 \\
\hline RML-5/RL-105 & 189.3 & 105.33 & 59.33 & 64 & 4.667 & 16.5 & 7.2 & 16 & 36.33 & 374.7 & 5528 \\
\hline RML-95/RL-105 & 196.7 & 111.33 & 55.67 & 60.33 & 4.667 & 15.79 & 7.633 & 17.33 & 35 & 370.7 & 5904 \\
\hline RML-115/RML-96 & 184.3 & 111.33 & 58.67 & 63 & 4.333 & 12.81 & 7.68 & 16.67 & 31.33 & 381.7 & 5294 \\
\hline RML-153/RL-105 & 186 & 115.33 & 55 & 59.67 & 4.667 & 16.69 & 7.28 & 16 & 34.67 & 380.7 & 5522 \\
\hline RML-85/RL- 105 & 186.7 & 119.33 & 54 & 58.67 & 4.667 & 15.27 & 7.393 & 17.33 & 35 & 363.7 & 5474 \\
\hline RML-98/RL-105 & 196.7 & 115.33 & 62 & 66.33 & 4.333 & 16.4 & 7.48 & 16 & 36.33 & 395.7 & 6229 \\
\hline Rajkumar & 176 & 96.67 & 46 & 49.33 & 3.333 & 13.5 & 4.833 & 14 & 27 & 347.3 & 4087 \\
\hline RML-4/NML-2 & 163 & 99.67 & 59.33 & 64.33 & 5 & 15.33 & 7.433 & 16.67 & 32.67 & 351.7 & 6073 \\
\hline Grand mean & 178.5 & 103.7 & 56.55 & 60.76 & 4.25 & 14.83 & 6.54 & 15.80 & 31.25 & 348.6 & 4932 \\
\hline $\mathrm{F}$ test & ns & ns & ns & ns & ns & ns & ns & ns & ns & ns & . \\
\hline $\operatorname{LSD}(0.05)$ & 18.2 & 14.4 & 10.1 & 9.7 & 4.2 & 2.1 & 2.7 & 8.4 & 3.8 & 12.2 & 39.1 \\
\hline CV \% & 7.8 & 8.1 & 12.4 & 11.6 & 13.3 & 8.7 & 3.8 & 5.3 & 7.6 & 7.2 & 21.2 \\
\hline
\end{tabular}

${ }^{*}=$ Significant at 0.05 level of significance, $n s=N o t$ significant. $P H=$ plant height $(\mathrm{cm}), C H=c o b$ height $(\mathrm{cm}), D T T=$ days to $50 \%$ tasseling, DTS = days to $50 \%$ silking, ASI= anthesis silking interval, TW= test weight $(1000 \mathrm{kernel}$ weight) $(\mathrm{g}), C L=\mathrm{cob}$ length $(\mathrm{cm}), C D=$ cob diameter $(\mathrm{cm}), N K R / C=$ number of kernel rows per cob, $N K / R=$ number of kernels per row, $G Y=$ grain yield (kg).

The single cross hybrids viz., RML-98/RL-105(6229 $\left.\mathrm{kg} \mathrm{ha}^{-1}\right)$ produced significantly the highest yield followed by RMl-4/NML-2 (6073 kg ha-1), RML-95/RL-105 (5904 kg ha-1) and RML-5/RL-105 (5528 kg ha-1), respectively. They produced grain yield $>5500 \mathrm{~kg} \mathrm{ha}^{-1}$, thus regarded as the best hybrids for commercial maize production. Koirala et al. (2013) found that the grain yield of hybrids ranged from $3810 \mathrm{~kg} \mathrm{ha}^{-1}$ to $9897 \mathrm{~kg} \mathrm{ha}^{-1}$. Grain yield was substantial, and these findings matched those of Akbar et al. (2009), who evaluated and identified high-yielding maize varieties among the various genotypes studied. Prasai et al. (2015) observed significant differences in grain production among maize varieties, and our findings are consistent with their findings.

Correlation coefficient of yield components and grain yield per plant had positively the highest and highly significant correlation with cob diameter, number of kernels per row, cob height, plant height, cob length, test weight and number of kernel rows per cob. Correlation among the different traits of maize genotypes along with checks is presented in (Table 3 ). Plant height was highly significantly correlated to cob height. Plant height had weak significant positive correlation to days to $50 \%$ silking and days to $50 \%$ tasseling but strong correlation with anthesis silking interval, test weight, cob length, cob diameter, number of kernel rows per cob, number of kernels per row and grain yield. Cob height had weak significant positive correlation to days to $50 \%$ silking and $50 \%$ tasseling but strong correlation with anthesis silking interval, test weight, cob length, cob diameter, number of kernel rows per cob, number of kernels per row and grain yield. Days to $50 \%$ tasseling was strong correlation with days to silking, anthesis silking interval, cob diameter, weak but positive correlation with number of kernels per row, number of kernel rows per cob, test weight and grain yield. Days to $50 \%$ silking was strong correlation with anthesis silking interval, cob diameter, test weight and grain yield but positive or weak correlation with cob length, number of kernels per row, number of kernel row per cob. Anthesis silking interval was strong correlation with cob length, cob diameter, number of kernels per row, number of kernel row per cob, test weight and grain yield. Cob length was strong correlated with cob diameter, number of kernel row per cob, test weight and grain yield. Cob diameter was strong correlated with number of kernels per row, number of kernel row per cob, test weight and grain yield. Number of kernel row was strongly correlated with number of kernel rows per cob, test weight and grain yield. Number of kernel rows per cob was strong correlated with test weight and grain yield. Test weights were strong correlated with the grain yield. The 
grain yield of tested genotypes was strong correlated with all traits except day to $50 \%$ tasseling was weak but positive correlation. Positive correlation coefficient among traits showed that the changes of two variables were same direction i.e., high value of one variable was associated with high value of another and vice versa. However, the most yield determinative traits were cob length followed by cob diameter, number of kernels per row, number of kernel row per cob, test weight, plant height and cob height.

Cob length was strongly correlated with cob diameter $(0.885)$, no of kernel per row (0.812), number of kernel row per cob (0.951), test weight $(0.870)$ and grain yield $(0.916)$. Similarly, Cob diameter was strongly correlated with number of kernels per row $(0.870)$, number of kernel rows per cob (0.934), test weight (0.922) and grain yield (0.946). The number of kernels per row was strongly correlated with number of kernel rows per cob $(0.915)$, test weight $(0.781)$ and grain yield $(0.847)$. The number of kernel rows per cob was strongly correlated with test weight (0.902) and grain yield (0.942). Similarly, test weight was strongly correlated with grain yield (0.968). Similar results were also reported by Ram Reddy et al. (2011), and Satyanarayana et al. (1990). Compton (1979) showed that plant height and cob height of maize populations were positively correlated with grain yield. Nkomo et al. (2013) showed that tasseling is one of the most important stages in maize production. Saleem et al. (2002) reported similar findings for number of kernel row per cob. Similarly (Hallauer and Miranda, 1988) reported strong positive correlation between plant height and cob height and between kernel weight and yield. Dagne (2008) also showed that the positive and highly significant phenotypic and genotypic correlations between grain yield and plant height, cob height, cob diameter, cob length, number of kernels per row and thousand kernel weight. Grain yield showed highly significant positive correlation with plant height (Sharma et al., 1982; Singh et al., 1991), cob length, cob circumference (Appadurai and Nagarajan,1975, Alok Kumar et al., 1999), number of kernel rows per cob, number of kernels per row (Appadurai \& Nagarajan, 1975), 100-grain weight (Saha \& Mukherjee, 1985; Tyagi et al., 1988,).

Table 3 - Pearson correlation coefficient of grain yield and yield components of single cross maize hybrids

\begin{tabular}{|c|c|c|c|c|c|c|c|c|c|c|c|}
\hline Traits & $\mathrm{PH}$ & $\mathrm{CH}$ & DTT & DTS & ASI & $\mathrm{CL}$ & CD & NK/R & NKR/C & TW & GY \\
\hline $\mathrm{PH}$ & 1.0 & & & & & & & & & & \\
\hline $\mathrm{CH}$ & 0.940 & 1.0 & & & & & & & & & \\
\hline DTT & 0.381 & 0.403 & 1.0 & & & & & & & & \\
\hline DTS & $0.428^{*}$ & 0.446 & $0.995^{* *}$ & 1.0 & & & & & & & \\
\hline ASI & $0.632^{* *}$ & $0.599^{* *}$ & $0.579^{* *}$ & $0.655^{* *}$ & 1.0 & & & & & & \\
\hline$C L$ & 0.834 & 0.838 & $0.289^{\text {ns }}$ & 0.348 & $0.655^{*}$ & 1.0 & & & & & \\
\hline CD & 0.868 & $0.871^{\text {x }}$ & $0.535^{x-}$ & $0.594=$ & $0.804=$ & $0.885^{* x}$ & 1.0 & & & & \\
\hline NK/R & $0.842^{* x}$ & $0.890^{* *}$ & $0.433^{*}$ & $0.473^{*}$ & $0.605^{* x}$ & $0.812^{* *}$ & $0.870^{* *}$ & 1.0 & & & \\
\hline $\mathrm{NKR} / \mathrm{C}$ & $0.902^{* *}$ & $0.892^{* *}$ & $0.393^{*}$ & 0.448 & $0.695^{*}$ & $0.951^{* *}$ & $0.934^{* x}$ & $0.915^{*}$ & 1.0 & & \\
\hline TW & $0.905^{* *}$ & $0.843^{* *}$ & $0.432^{*}$ & 0.498 & $0.810^{* *}$ & 0.870 ** & $0.922^{* *}$ & $0.781^{* *}$ & $0.902^{* *}$ & 1.0 & \\
\hline GY & $0.924^{* *}$ & $0.890^{* *}$ & $0.398^{*}$ & $0.465^{*}$ & $0.794^{* *}$ & $0.916 *$ & $0.946^{* *}$ & $0.847^{* *}$ & $0.942^{* *}$ & $0.968^{* *}$ & 1.0 \\
\hline
\end{tabular}

${ }^{*}=$ Correlation is significant at the 0.01 level, ${ }^{*}=$ Correlation is significant at the 0.05 level, $n s=$ Not significant at 0.05 level, $\mathrm{PH}=$ plant height $(\mathrm{cm}), \mathrm{CH}=\mathrm{cob}$ height $(\mathrm{cm}), \mathrm{DTS}=$ days to $50 \%$ silking, DTT= days to $50 \%$ tasseling, ASI= anthesis silking interval, $T W=$ test weight $(1000$ kernel weight) $(\mathrm{g}), \mathrm{CL}=\mathrm{cob}$ length $(\mathrm{cm}), \mathrm{CD}=$ cob diameter $(\mathrm{cm}), \mathrm{NKR} / \mathrm{C}=$ number of kernel row per cob, $\mathrm{NK} / \mathrm{R}=$ number of kernels per row, $\mathrm{GY}=$ grain yield $(\mathrm{kg})$.

Therefore, the traits viz., plant height, cob height, cob length, cob diameter, number of kernels per row, number of kernel rows per cob and test weight plays vital role to increase the grain yield of maize.

\section{CONCLUSION}

The grain yield of evaluated maize hybrids was strongly correlated with all traits viz cob length, cob diameter, number of kernels per row, number of kernel rows per cob, test weights; these traits might bring an improvement in grain yield. There were highly significant variations among the evaluated hybrids for grain yield and other yield attributing traits which indicated presence of high magnitude of genetic variations. The single cross hybrids RML98/RL-105 produced the highest yield followed by RMl-4/NML-2, RML-95/RL-105 and RML- 
$5 / R L-105$. Therefore, the findings of this study suggest that farmers should cultivate these hybrids for achieving higher maize production.

\section{ACKNOWLEDGEMENTS}

The authors express their gratitude and sincere thanks to National Maize Research Program, Rampur, Chitwan, Nepal for providing research fund, plant materials, field and other technical supports to carry out this study.

\section{REFERENCES}

1. Adhikari, J. (2014). Seed sovereignty: Analyzing the debate on hybrid seeds and GMOs and bringing about sustainability in agricultural development. Journal of Forest and Livelihood, 12, 33-46.

2. Akbar, M., Saleem, M., Ashraf, M.Y., Hussain, A., Azhar, F.M., \& Ahmad, R. (2009). Combining ability studies for physiological and grain yield traits in maize at two temperatures. Pakistan Journal of Botany, 41(4), 1817-1829.

3. Alok Kumar, Gangashetti, \& Arju Dahiya, H. G. (1999). Analysis of direct and indirect effects of quantitative traits in diallel crosses of maize. Annals of Biology , 15, 173-176.

4. Appadurai, R., \& Nagarajan, R. (1975). Hybrid vigour in popcorn. Madras Agricultural Journal, 62, 122-126.

5. Carangal, V.R., Ali, S.M., Koble, A.F., \& Rinke, E.H. (1971). Comparison of S1 with testcross evaluation for recurrent selection in maize. Crop Science, 11: 658-661.

6. CDD. (2013). Crop Development Directorate. Impact of maize mission program. http://cddnepal.gov.np/uploaded/Impact Maize Mission Program.pdf

7. Compton, W.A., Mumm, R., \& Mathema, B. (1979). Progress from adaptive mass selection in incompletely adapted maize populations. Crop Science, 19, 531-533.

8. Dagne Wegary. (2008). Genotypic variability and combining ability of quality protein maize inbred lines under stress and optimal conditions. PhD thesis, University of the Free State, South Africa, p.321.

9. Gomez, A. K., \& Gomez, A. A. (1984). Statistical procedures for agricultural research, 2nd edition. John and Sons, inc., Institute of Science pub. New York. p679.

10. Gurung, D. B., Upadhyay, S. R., Pandey, B. R., Pokhrel, B. B., \& Kshetri, J. B. (2011). Hybrid maize seed production: A new initiative for reliable and sustainable hybrid maize seed supply. Nepal Agriculture Development Journal, 8, 1-8.

11. Hallauer, A.R., \& Miranda, J.B. (1988). Quantitative genetics in maize breeding. 2nd ed. lowa State University Press. Ames, IA. Pp. 356-457.

12. Khadka, D., Lamichhane, S., Thapa, B., Baral, B. R., \& Adhikari, P. (2016). An assessment of soil fertility status of national maize research program, Rampur, Chitwan, Nepal. Imperial Journal of Interdisciplinary Research, 2(5), 1798-1807.

13. Khodambashi, M, \& Harsmand, S. (2012). Correlation and International Path coefficient Analysis of seed yield related traits in maize. Journal of Agriculture and Crop Sciences 5 $-15,2217-2220$.

14. Koirala, K. B., Gurung, D. B., Kunwar, C. B., Tripathi, M., Thakur, P., Bhandari, G., Bhandari, B., Shrestha, J., Karki, T. B., Baral, B. R., Adhikari, P., Achhami, B. B., BK, S. B., Bhurer, K. P., Chaudhary, B. N., \& Chhetri, J. B. (2013). Evaluation of multinational companies' maize hybrids during winter season of 2010-2012. Proceedings of the 27th National Summer Crops Workshop 2.

15. Lucchin, M., Barcaccia, G. \& Parrini, P. (2003).Characterization of a flint maize (Zea mays L. convar. mays) Italian landrace: I. Morpho-phenological and agronomic traits. Genetic Resources and Crop Evolution 50, 315-327. https://doi.org/10.1023/A:1023578207258

16. MoAD. (2013). Statistical Information on Nepalese Agriculture. Government of Nepal, Ministry of Agriculture Development Agri-business Promotion and Statistics Division. Singha Durbar, Kathmandu, Nepal. 
17. MoAD. (2020). Statistical Information on Nepalese Agriculture. Government of Nepal, Ministry of Agriculture and Cooperatives. Agri-business Promotion and Statistics Division. Singha Durbar, Kathmandu, Nepal.

18. Nkomo, G.V., Mapanda, F., Chiteka, A.Z., \& Mutezo, W.T.(2013). Short-term effects of seed-dressing with associative-nitrogen-fixing bacteria on flowering, silking and yield of maize in Zimbabwe. International Working Paper Series, 04, 2-12.

19. Pokhrel, T. (2013). Impact of Maize varieties Disseminated in Chitwan, Nepal. Economic Journal of Nepal, 42(6), 45-53.

20. Prasai, H.K., Kushwaha, U.K.S., Joshi, B.P., \& Shrestha, J. (2015). Performance evaluation of early maize genotypes in far western hills of Nepal. Journal of Maize Research and Development, 1(1), 106-111.

21. Ram Reddy, V., Seshagiri Rao, A., \& Sudarshan, M. R. (2011). Heterosis and combining ability for grain yield and its components in maize (Zea mays L.). Journal of Research, ANGRAU, 39(3), 6-15.

22. Saha, B. C., \& Mukherjee, B. K. (1985). Analysis of heterosis for number of grains in maize (Zea mays L.). Saha, B. C., \& Mukherjee, B. K. (1985). Analysis of heterosis for number of grains in maize (Zea mays L.). Indian J. Plant Breeding, 45, 240-246.

23. Saleem, M., Shahzad, K., Javid, M., \& Ahmed, A. (2002). Genetic analysis for various quantitative traits in maize (Zea mays L.) inbred lines. International Journal of Agriculture Biology, 4, 379-382.

24. Sapkota, D., \& Pokhrel, S. (2010). Community based maize seed production in the hills and mountains of Nepal: A review. Agronomy Journal of Nepal, 1, 107-112.

25. Satyanarayana, E., Saikumar, R., \& Koteswar, R. (1996).Character association or grain yield with some yield components in maize (Zea mays L.).Madras Agriculture

26. Sharma, S. R., Khera, A. S., Dhillon, B. S., \& Malhotra, V. V. (1982). Evaluation of S1 lines of maize crossed in a diallelic system. Journal of Crop Improvement, 9, 42- 47.

27. Shrestha, J. (2016). Cluster analysis of maize inbred lines. Journal of Nepal Agricultural Research Council, 2, 33-36.

28. Singh, S. N., Singh, K. N., \& Singh, H. G. (1991). Genetic variability and interrelationship in maize. Narendra Deva journal of agricultural research, 6, 233-237.

29. Smith, J. C., \& Smith, O. S. (1989). The description and assessment of distances between inbred lines of maize. II: The utility of morphological biochemical, and genetic descriptors and a scheme for the testing of distinctiveness between inbred lines. Maydica, 34(2), 151-161.

30. Tyagi, A. P., Pokhariyal, G. P., \& Odongo, O. M. (1988). Correlation and path coefficient analysis for yield components and maturity traits in maize (Zea mays L.). Maydica, 33, 109-119. 